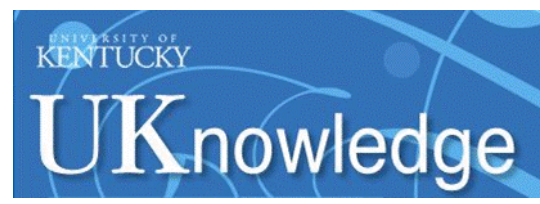

Kentucky Law Journal

\title{
The Interurban Electric Railway as a Modern Development of the Use of the Streets and Highways or as an Additional Burden
}

Clarence A. Beutel

Follow this and additional works at: https://uknowledge.uky.edu/klj

Part of the Transportation Law Commons

Right click to open a feedback form in a new tab to let us know how this document benefits you.

\section{Recommended Citation}

Beutel, Clarence A. (1916) "The Interurban Electric Railway as a Modern Development of the Use of the Streets and Highways or as an Additional Burden," Kentucky Law Journal: Vol. 4: Iss. 5, Article 8. Available at: https://uknowledge.uky.edu/klj/vol4/iss5/8

This Note is brought to you for free and open access by the Law Journals at UKnowledge. It has been accepted for inclusion in Kentucky Law Journal by an authorized editor of UKnowledge. For more information, please contact UKnowledge@lsv.uky.edu. 
THE INTERURBAN ELECTRIC RAILWAY AS A MODERN DEVELOPMENT OF THE USE OF THE STREETS

\section{AND HIGHWAYS OR AS AN ADDDITIONAL \\ BURDEN.}

New and interesting questions of law have arisen by reason of the extension of the electric street railway of the city into the country, its operation over the country highway and final development into the modern interurban railway. Whether such a railway is an additional burden on the streets and highways over which it is constructed and operated, is an important and much disputed question and one affecting the rights of the abutting owners, rural steam railroads and the public generally.

It is weil settled by the weight of authority that a steam or commercial railroad is an additional burden both upon the city streets and the country highways. On the other hand, the courts almost universally hold that the street railway operating upon the streets of a municipality does not constitute an additional servitude.

The interurban railway, however, to some extent partakes both of the nature of the street railway and the commercial railroad. It was at first merely an extension of the street railway into the suburbs and was used to carry passengers from the city to various points along the suburban road. Upon the perfection of electric motive power these suburban roads extended their lines to adjoining towns and have gradually built up a system which forms a net-work of interurban traffic over a large portion of this country. The urban railway developed into the suburban and the interurban and is now rapidly becoming an interstate system.

An interurban railway may be defined as a railway operated on the street of a city or town by electricity or by power other than steam which extends beyond the corporate limits of said city, town or village, or any railway operated by power other than steam extending from one city, town or village to another city, town or village. ${ }^{1}$

It usually has many of the characteristics of the street railway when operated within a municipality, it runs its cars upon the streets,

1.-See Cedar Rapids Ry. Co. vs. Cummins, 125 Ia. 430. 
stops at the street corners for the accommodation of passengers and its road-bed is constructed so as to conform to the grade of the street and the rails laid so as not to materially interfere with the traffic thereon. In the country, however, the modern interurban is often built upon private right of ways, stops only at designated stations at frequent intervals, runs at a high rate of speed, is engaged principally in through traffic between cities and towns, and its road bed is usually constructed with the "T" rail, and, in some cases, upon graded and rock-ballasted roads. Many lines carry express and light freight and even special freight cars, and, in some parts of the west, sleeping cars are now operated. They usually exercise powers not enjoyed by street railways, such as the power of eminent domain for the acquisition of a private right of way or the operation of freight cars. $^{2}$

It will readily appear that the interurban railway creates an entirely new problem. There is considerable difference of opinion as to the doctrine on which the determination of the question of whether a railway imposes a new burden depends. It is said in some cases that the electric street railway is not an additional burden because it is merely a modern development from the private vehicle and stage coach of former time and the same law should apply to both, but there is a distinct difference between the street railway and the ordinary vehicle in that it runs upon fixed tracks, turns aside for no one, obstructs the streets with poles, and by its wires increases the hazard of the use of the highway. In some cases the carriage of freight is held to be the fact which distinguishes the commercial railroads from the street railway, and determines whether the interurban is a commercial road, and, as such, imposes an additionaly servitude. ${ }^{3}$

The only satisfactory test, is whether the operation of the traction railway upon the street or highway is in furtherance of the uses of the highway for which it was originally intended, that is, to accommodate the public travel and to afford persons the opportunity to go from one part of the city or town to another on foot or in vehicles with such movable property as they wish to transport.

2.-Diebold v. Kentucky Traction Co., $117 \mathrm{Ky} .146$.

3.- Wilder vs, Aurora Traction Co., 216 Ilil. 493.

5.-Fiss v. Baltimore Pass. Ry. Co., 52 Ma. 542; W. Jersey Ry. Co. va Camden Ry. Co., 52 N. J., Ey. 31, 29 Atl. Rep. 423. 
The easement acquired by the public in a street or highway is the right to use it, not only according to the existing modes of travel and transportation, but also according to all such other modes as may arise in the ordinary course of improvement which are in furtherance of the intention of the original dedication or condemnation; but the use of the street cannot be so enlarged as to accumulate burdens on the land not originally contemplated. ${ }^{6}$

The street railway facilitates the travel upon the streets of a municipality and thus relieves the sidewalks of passengers and the roadway of vehicles. It may therefore be said to be an aid to the easement of passage. On the other hand, if the railroad occupies all or a portion of the highway so as to continually interfere with the travel of the public thereon, it is an obstruction to the easement of passage and a new burden is thereby imposed. A steam railroad occupies the highway, but does not relieve it. It carries passengers from long distances into a city, accommodates itself only very incidentally to local traffic, and it operates large trains of cars so as to interfere materially with the use of the street and so deprives the public of the beneficial enjoyment thereof.

Where the interurban railway operates its cars in the streets of a city in the same manner as a street railway, stops at the street corners for the accommodation of passengers, constructs its roadbed so as to conform with the grade of the street, runs at a moderate rate of speed and does not interfere with the traffic on the highway, it may be said to be in furtherance of the purposes of the street and not an additional burden thereon. ${ }^{7}$

If, however, a railway is engaged primarily in interurban traffic and large interurban cars pass through the town for the principal pupose of carrying through traffic to other towns; it does not relieve traffic of the street, but increases the burden of the city or town by carrying over its streets carloads of persons and property from other localities, merely passing through and imposes additional servitude.

In Younkin vs. Milwaukee Traction Company, I20 Wis. 477, 99 N. W. Rep. 2I 5 , the court says:

"The defendant claims the right to run its trains and cars from

v. Coal Co., Jersey Ry. Co. v. Camden Ry. Co., 52 N. J. Eq. 31; Lonaconning Ry. Co. 7.-Watson v. Fairmont Ry. Co., 49 W. Va. 528; Jeffers v. Indianapolis, 68 Atl. 361. 
the city of Milwaukee directly through the city of Waukesha and to Waukesha Beach. In doing so it is conceded that, while such trains or cars are interurban, they do cast an additional burden on the lands of abuttitng owners, which entitles them to compensation; but it is claimed that the moment such trains of cars pass into the city of Waukesha they cease to cast any such additional burden upon the lands of such abutting owners. And yet such trains of cars may be loaded with through passengers. The only difference is that while in the City of Waukesha such trains of cars, in obedience to requirements stop at street crossings, whereas in the country they only stop when convenient, or at points remote from each other. Counsel for the defendant argues that as the trains or cars with passengers from Milwaukee might, at the city limits of Waukesha, change from such interurban cars to regular street cars, and then at the westerly limits of the city again change into interurban cars, therefore, it is substantially the same as though the interurban trains or cars should continue with its passengers directly through the city; especially as the ordinance expressly authorized the street railway to connect with the interurban railway. While such argument may be plausible, yet it is really begging the question. It might be argued on the same theory that a commercial railway passenger train, with the permission of the city, might be run over the street railway tracks without compensation to the abutting lot owners. We must hold that the running of such interurban trains and cars over the street railway tracks upon Lincoln Avenue was an additional burden upon the lands of the plaintiffs as such abutting lot owners."

The contrary view, however, is taken in several jurisdictions upon the ground that the interurban railway is merely a modern development of the use of the street and is not new but merely an ancient form of travel by improved means consistent with the general uses of the street. In a very interesting case the Supreme Court of Indiana decided by a divided court of three to two that the operation of an interurban railway within a city over the tracks of the street railway does not constitute additional burden although the railway was authorized to carry freight in the city and was operating a railway of a commercial nature. (Kinsey v. Union Traciton Co., I69 Ind. $56 \mathrm{r}$. 
It is apparent that the opinion of the majority of the court is based upon the assumption that local public interest and convenience for the carriage of passengers and freight out of the city overbalanced the additional burden of the railway upon the streets. It is difficult to see how the arguments in support of the decision will not apply with equal force to a steam railroad. A,s the minority judge says, the semblance of such a road to the steam railroad is so close that a distinction cannot reasonably be drawn and the difference is merely one of: degree and not of character of burden imposed.

An entirely different question arises when we consider the relation of the interurban railway to the abutting owners upon a country road over. which it is operating its cars. The public necessities of the streets in a municipality are greater, and therefore, it may be contended that increased burdens may be properly imposed upon them. The court says in Van Brunt v. Flatbush, I28 N. Y. 50, 27 N. C. Rep. 973 :

"In the ordinary country highways of the state, the public simply have an easement in the soil for traveling. The public easements, however, in the streets of cities and villages are more extensive. In urban streets the public convenience and health, and the general welfare require that the soil thereof should be subjected to greater burdens. They may be used for the laying of water and gas pipes, and the construction of sewers, and some other purposes. The public generally have an interest in and are benefited by such improvements, and they are necessities of modern life."

The rule that the imposition of an additional burden depends upon whether the interurban railway is in furtherance of the uses of the highway for which it was originally intended, applies with perhaps greater force to the country road than to the streets of the city.

It has been held that where a street railway company runs its cars into the country upon roads which are merely extensions of the city streets, for the purpose of carrying persons to and from its suburbs, it partakes of the nature of a street railway and is not an additional burden. (Floyd v. Home Ry. Co., 77 Ga. 6I4.)

When, however, the interurban car is operating principally for the carriage of through passengers or freight from one city to another and only incidentally and to a small degree for the accommoda- 
tion of local traffic, the railway is not serving the purposes of the dedication 'of the road except in a limited sense, but on the contrary burdens the highway with travel which would not otherwise be there. (Goddard v. Chicago Ry. Co., IO4 Illi. App. 532; Hiss v. Baltimore Pass. Ry. Co. $5^{2}$ Md. 542.)

A number of cases base their decision, that the interurban is an additional burden, upon its resemblance to the steam road, concluding that it is a commercial railroad and, as such, is governed by the same law as the steam road. The underlying principle, however, is not that an interurban railway of such character resembles the steam road, but that such a use of the highway is contrary to the purpose of its dedication or appropriation by burdening it with additional traffic and permanent obstructions.

There are a number of cases seemingly in conflict with the general weight of authority, but almost every case can be reconciled by the fact that the railway resembled the street railway in construction and equipment and was operated principally for the accommodation of local traffic.

Whether an interurban railway is an additional servitude, therefore, is largely a question of fact and depends on whether it resembles in character a street railway and operates its cars for the accommodation of local traffic, or whether it resembles a commercial railroad and operates its cars for interurban and through traffic.

The whole question, insofar as it affects the abutter, depends upon whether he owns the fee of the street, over which the car passes, subject to the public easement. Where the title to the public streets and highways is vested in the public, the abutter has only in addition to such public easement, its right of ingress or egress to and from his premises, and an action against the traction company for damages only in case of obstruction thereto. (Chicago Ry. Co. 95 Wisc. 56I, 70 N. W. 673; Schaf v. Cleveland Ry. Co., 66 Ohio St. 2I5; Lanaconing Ry. Co. v. Coal Co. 95 Md. 630; Ehret v. Canden Ry. Co. 6I N. J. Eq. I7I, 47 Atl. Rep. 562.)

To summarize, we find that the question of additional servitude is based, by the predominant weight of authority, upon the question whether the operation of the railroad or railway, upon the street or highway, is consistent with the uses for which they were intended in 
the original dedication and appropriation, and the courts are also taking more into consideration the question whether the local public service rendered by the interurban railway outweighs the burden imposed by it upon the streets and country roads.

CLARENCE A. BEUTEL, L. L. B., Louisville Bar.

\section{BITS OF HUMOR.}

\section{Proofs Were Lacking.}

Here is a little story printed in the Philadelphia Telegraph, that was recently told by Representative William H. Murray, of Oklahoma, in gently throwing the harpoon into a lawyer friend:

One afternoon a stranger debarked from a train at a hustling town in the west, and headed up the street. Finally he met a party that looked like a native.

"Pardon me," said the stranger, halting the likely looking party. "Are you a resident of this town?"

"Yes, sir," was the ready rejoinder of the other. "Been here something like fifty years. What can I do for you?"

"I am looking for a criminal lawyer," responded the stranger. "Have you one here?"

"Well," reflectively answered the native, "we think we have, but we can't prove it on him."-Case and Comment.

\section{Fair Division.}

Scene-Police court during dispute over eight-day clock.

Magistrate-I award the clock to the plaintiff.

Defendant-Then what do I get?

Magistrate-I'll give you the eight days.--Stray Stories.

\section{A Hot Trail.}

Jefferson county constables expect to have no difficulty in trailing the desperate men who committed a robbery hitherto unrecorded in the annals of Kentucky crime. They raided the skunk farm of 